



\title{
The Comparative Viability of Seeds, Fungi ANd Bacteria When Subjected to Various Chemical AgEntS
}

\author{
A THESIS \\ SUBMITTED TO THE FACULTY OF THE DEPARTMENT \\ OF LITERATURE, SCIENCE AND THE ARTS OF \\ THE UNIVERSITY OF MICHIGAN FOR \\ THE DEGREE OF DOCTOR \\ OF PHILOSOPHY \\ BY \\ RICHARD DE ZEEUW
}

ANN ARBOR

IgII 



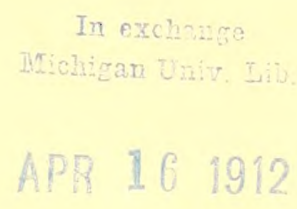

Abdruck aus dem

Centralblatt für Bakteriologie, Parasitenkunde und Infektionskrankheiten. II. Abteilung.

Herausgeg. von Prof. Dr. 0. Uhlworm in Berlin. - Verlag von Gustav Fischer in Jena. Bd. 31. 1911. No. $1 / 4$. 
Nacharuck verboten.

\title{
The comparative Viability of Seeds, Fungi and Bacteria when subjected to various chemical Agents.
}

\section{Richard de Zeeuw.}

\author{
With 1 Textfigure.
}

The following work was undertaken because of the lack of conclusive evidence that it is possible to obtain seeds for experimental purposes, free from contaminating organisms.

All of the work was done in the botanical laboratory of the University of Michigan, under the supervision of Professor $\mathrm{New}$ e o m b e, to whom I wish to acknowledge my indebtedness. For valuable aid and helpful suggestions on the mycological side of the problem, I am greatly indebted to Prof. J. B. P o ll o e k, also of this laboratory. To Dr. F. G. No v y of the medical department, I am indebted for some valuable suggestions on the bacteriological side, also to his assistant, $\mathrm{Mr}$. W. A. P e r k in s, for valuable practical aid.

\section{Historical.}

Very little has been done to study the comparative viability of seeds, fungi and bacteria when treated with different disinfecting agents. It is only within recent years that any work having that end in view has been done. The attempted object is to obtain good seedlings, free from bacteria and fungi, 
for experimental purposes. The earlier efforts along the line of sterilization were to sterilize the hands, articles of elothing, rooms, ete. For the hands, mereuric chloride mainly was used. Some valuable suggestions as to its antiseptic action may be obtained from the work of $\mathrm{F}$ ü r b r i n g e r and F re $\mathrm{y}$ $\mathrm{h}$ a $\mathrm{n}$ (1897) and of $\mathrm{D}$ a $\mathrm{ni} \mathrm{i} \mathrm{s}$ o h $\mathrm{n}$ and $\mathrm{Hess}$ (1902). The work along these lines is suggestive of the possibility of obtaining seedlings, free from bacteria and fungi, for experimental purposes.

After sulphur was found to be, not valueless, but inadequate, for room sterilization, attention was more and more directed to formaldehyde. It is conceded quite generally that formaldehyde is valuable only as a surface disinfectant. Special emphasis is laid on this point by $\mathrm{Novy}$ and $\mathrm{W}$ a it e (1898) in their paper on ,Disinfection of Rooms." They found that dried or covered infectious material was not necessarily killed even after twenty hours exposure to the gas. M ï 11 e r (1901) also came to the conclusion that only exposed bacteria are killed; further, that these must be vegetating forms. Rubner and Peerenboom (1899) found that horizontal surfaces might be sterilized by means of formaldehyde, while vertical surfaces were not in the least affected. This they ascribe to a condensation of the formaldehyde gas, causing it to settle in disinfecting quantities on the horizontal surfaces, while the vertical surfaces receive no such deposit.

The work done on seeds with formaldehyde is, as a general rule, very unsatisfactory. Kehler (1904) did some work in that direction, but he found that his seeds were more sensitive to the action of formaldehde than the spores of either bacteria or fungi, when its action went deeper than the mere surface, as is absolutely essential if one is to obtain sterile seeds. The work of W e r n e r (1904) indicates that a stronger solution of formaldehyde than seeds can bear is necessary to kill even exposed bacterial spores. Chester and Brown (1905), studying the action of formaldehyde in milk, found that it took a one-eighth percent solution over five days to kill Bacillus subtilis. B o s c (1896) found that it took five hours to kill pathogenic germs on eloth well exposed to formaldehyde gas. S t e r n b e r g (1901) and P a r k (1905) lay greater emphasis than any of the others on the chemical action of formaldehyde in disinfection. M o r s e (1907) found that formaldehyde will kill $\mathrm{Phytophthora}$ infestans, a parasitic fungus, on seed potatoes, without injuring the potatoes.

The best results to date in sterilization were obtained by the use of mercuric chloride. Ke h le r (1904) found that copper sulphate killed seeds so quickly that it was valueless as a disinfecting agent. He, however, obtained excellent results with mercuric chloride. M i y a ji ma (1897) found that a 0,3 per cent solution of mercuric chloride killed the seeds of $\mathrm{Z} \mathrm{e} \mathrm{a} \mathrm{m}$ a $\mathrm{y} \mathrm{s}$, $\mathrm{P}$ is u $\mathrm{m}$ sativu $\mathrm{m}$ and $\mathrm{Vic}$ i a $\mathrm{f}$ ab a. The harm was done by overexposure, the seeds being exposed for six hours or more. $\mathrm{C} z$ a p e $\mathrm{k}$ (1896) found that he could obtain sterile seeds of $\mathrm{Z} e$ a $\mathrm{m}$ a y s by polishing the dry seeds with a stiff brush till no more particles came off, then cleaning them, thoroughly with a brush, soap and warm, sterile, distilled water, and finally dipping them for two or three minutes in a 1 per cent solution of mercuric chloride, and then rinsing them once in sterile distilled water. This treatment, he claims, was sufficient to kill the fungus hyphae growing over the aleurone layer, but not into it.

Freeman (1904), working also on Lolium te mulentum, treated the seeds with a 1 per cent solution of mercuric chloride, but found 
only some of the seeds to be free from the fungus. S t e w a r d (1908) found that the seeds of $\mathrm{Z}$ e a $\mathrm{m}$ a $\mathrm{y} \mathrm{s}$ when subjected for one-half to three-quarters of an hour to a 0,5 per cent solution of mercuric chloride were still sterile at the end of fourteen or sixteen days. P a ul and Krön ig (1896) found that a two percent solution of mercuric chloride was unable in twenty-five minutes to destroy the spores of $\mathrm{B}$ a $\mathrm{e}$ ill $\mathrm{us}$ a $\mathrm{n} \mathrm{th} \mathrm{rac}$ is in a suspension dried on the surface of tare-garnets. B e h r i n $g$ (1888) attributed the failure of mercuric chloride in sterilization to the formation of mercuric albuminates. Nelson (1907), treating potatoes for Oospor a scabies, found that a 1 percent solution of mercuric chloride killed the parasite without injuring the potatoes. Some interesting work on the inhibition of bacteria was done by $\mathrm{P}$ a u $\mathrm{l}$ (1901). He found that a 1 to 1,000000 solution of mercuric chloride kept them in check without killing them. Geppert (1889) found that a suspension of B a cillus a n thracis dried on silk threads was prevented from developing by treating for ten minutes with a 0,1 percent solution of mercuric chloride. However, after having been treated for a half-hour with a 0,1 percent solution the organisms were caused to develop by precipitating the mercury with ammonium-sulphate. Eriksson (1905) attempts to explain the overwintering and consequently the persistence of wheat-rust under treatment by what he calls the Mycoplasm theory. He assumes that part of the protoplasm in the cells belongs to the host but that part of it belongs to the fungus and is to all apperance dormant. This theory appears rather fanciful in the light of the researches of Stow a r d (1908), H a $\mathrm{n} \mathrm{ig}$ (1908), B olle y and Prit c h a r d (1905) and others.

\section{Technique.}

The work laid in this study was to test the action of the following agents: cleaning fluid ${ }^{1}$ ), mercuric chloride, hydrogen peroxide, potassium dichromate, ammonium persulphate, bromine water (common), and formaldehyde gas, on the seeds of $\mathrm{Lupinus}$ al bus, Pisum sativum, Triticum vulgare, Hordeum vulgare, Zea mays and Sinapis a 1 b a.

The work can be convently divided into two parts. The first part has to do mainly with the seeds, the second mainly with the fungi and bacteria.

The first thing to be done is to determine the highest concentration and the longest period of exposure in each case which will still permit one to obtain a fair percentage of normal seedlings, leaving out of consideration for the time being the effect of the disinfectant on the adhering fungi and bacteria. A great deal of unnecessary and tedious work would be involved in determining the effect of the disinfectant on the fungi and bacteria adhering to the seeds while determining the effect on the germination of the seeds. The germination tests were carried on during the early fall when the laboratory had a normal temperature day and night of $22^{\circ} \mathrm{C}$. This temperature was fairly constant. Lots of twenty-five seeds each were exposed for different lengths of time to different concentrations of each of the disinfectants, and, after thorough washing, were placed in a Geneva germinator kept at room temperature. They were left for four or five days and were then compared with the controls. These controls were treated as nearly as possible in a

${ }^{1}$ ) Cleaning fluid $=\mathrm{H}_{2} \mathrm{SO}_{4}$ sp. gr. 1.83 saturated with $\mathrm{K}_{2} \mathrm{CrO}_{7}$. 
manner similar to the experimental seeds, except that no disinfectant was used.

After the highest point of both exposure and concentration had been determined for each kind of seeds in the different disinfectants, each kind of seeds thus treated was then tested to determine whether bacteria and fungi could endure this treatment as well as the seeds. For determining the latter point, an apparatus was constructed, the idea for which was obtained from Kehlers (1904) paper. It differs from Kehlers apparatus in that the seeds, after they are once placed in the disinfectant, are not exposed to contamination in any form till after a two weeks incubation. K e h l e r transferred his seeds by means of sterile forceps from the vessel in which they had been treated to the flask of culture medium.

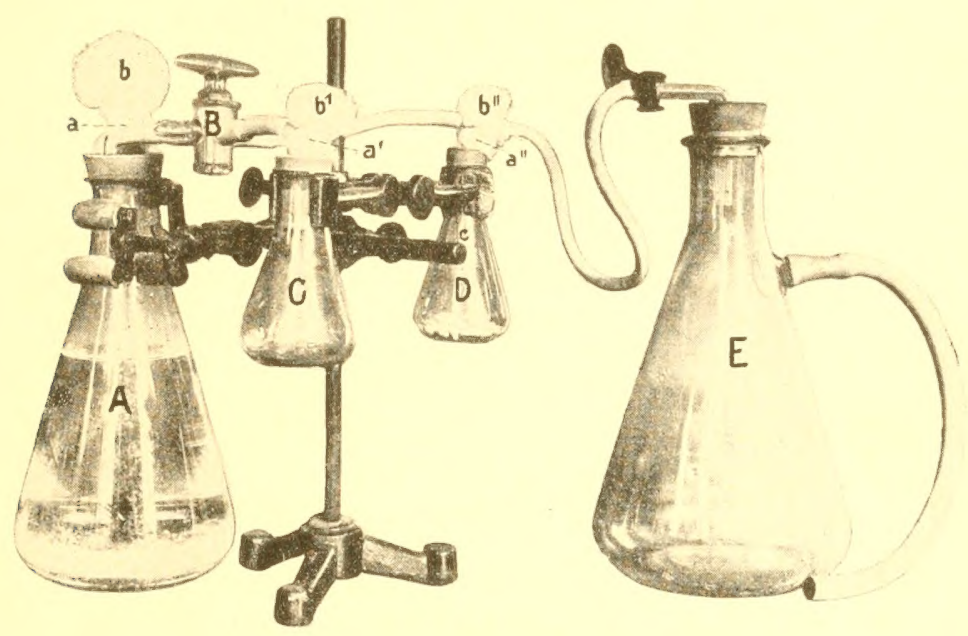

My apparatus (see te t-figure) is constructed as follows: There is a large flask, $\mathrm{A}$, which contains distilled water and is connected with a three-arm glass cock, B. Flask A also has a glass tube, a, with a flange worked on the end. This tube projects into the flask through the rubber stopper. Over the flanged end of the tube is securely fastened a cap of cotton, b, to filter the air as it enters the flask when the water is drawn out of the flask. To the tube on the opposite side of cock B, is attached a small flask C. This flask has also an upright flanged tube, $a^{\prime}$, with a cotton filter $b^{\prime}$. To the third tube of cock $A$ is attached another small flask D. In addition to the flanged tube, $a^{\prime \prime}$, with its cotton filter $b^{\prime \prime}$, it has a third tube, $c$, entering it. This tube is drawn to a point, dips to the bottom of the flask, being bent so as to end in the angle between the side wall and the bottom of the flask. Tube $\mathrm{c}$ is connected with cistern $\mathrm{E}$, which in turn is connected with an aspirator. Flasks A, C and D are supported on a low ringstand.

The apparatus is operated as follows: Flask $\mathrm{A}$ is filled with distilled water; into flask $\mathrm{C}$ is put $25 \mathrm{ccm}$ of agar medium; and $\mathrm{E}$ is disconnected after the rubber tube between $\mathrm{D}$ and $\mathrm{E}$ has been closed by means of a clamp. The whole apparatus (except the cistern) is then placed in the autoclave and sterilized. After autoclaving, flask C, while still attached to the ringstand, is introduced through a slot into a large cardboard cylinder. 
Around the arm supperting flask C is packed sufficient cotton to close the opening in the cylinder. E is again connected with the rest of the apparatus. When the apparatus has cooled sufficiently, the rubber stopper is removed from flask D, the seeds and the desired disinfectant are quickly introduced, and the flask is again closed tightly. Flask D is then thoroughly shaken, so that the disinfectant may come in intimate contact with the walls of the flask, the tube and the stopper. This is to destroy any spores that may have happened to enter when the flask was opened to admit the seeds and disinfectant. When the seeds have been in the disinfectant the required length of time, the disinfectant is drawn off into the cistern $\mathrm{E}$, by means of tube $\mathrm{c}$. The last drops can readily be removed by tilting flask $\mathrm{D}$. Water is then drawn through cock B from flask A, into flask D, upon the seeds. This is done by exhausting the air in cistern E. To prevent the air from entering flask D during this process, a rubber finger-cot can be drawn over b, or the finger may simply be pressed down on it. In that way the seeds can be washed as frequently as desired. After washing them, some of the agar medium is drawn from flask $\mathrm{C}$ by turning cock $\mathrm{B}$ so as to connect $\mathrm{C}$ and D. Agar solidifies at $42^{\circ} \mathrm{C}$. It is therefore kept at about $45^{\circ} \mathrm{C}$ until needed. That temperature will not harm the fungi or bacteria that may adhere to the seeds. Sufficient agar to cover the seeds is introduced. The rubber tubes between $\mathrm{D}$ and $\mathrm{C}$ and between $\mathrm{D}$ and $\mathrm{E}$ are closed by means of clamps. The rubber tubes are cut beyond the clamps and flask $\mathrm{D}$ is ready be set aside to incubate.

\section{Experimental.}

In all of the following germination experiments, all of the seeds were carefully inspected so as to obtain only perfect specimens. In all the germination experiments, each lot consisted of twenty-five seeds. The germination percentage, under ordinary laboratory conditions, of the seeds in the following experiments was as follows: L u p i n u s a $1 \mathrm{~b}$ u s 96 per cent, $\mathrm{P}$ is u m s a t i v u m 96 per cent, Tritic u $\mathrm{m}$ v u $\mathrm{g}$ a re 96 per cent, H or d e u m vulgare 92 per cent, Ze a M a y s 100 per cent, and S in a p is a $\mathrm{lb}$ a 96 per cent. The first agent used in treating the seeds was cleaning fluid $\left(\mathrm{H}_{2} \mathrm{SO}_{4}+\mathrm{K}_{2} \mathrm{Cr}_{2} \mathrm{O}_{7}\right)$. As far as $\mathrm{I}$ have been able to ascertain it has not been employed for the purpose before. It occured to me that cleaning fluid might be a very desirable agent to use since it penetrates no farther than it thoroughly oxidizes. Thus, by timing its action, we can destroy as much of the seed-coat as is safe under any given condition, and also the adhering fungus and bacteria spores, even such fungus hyphae as may have penetrated part way into the seed-coat. From what I knew of the properties of cleaning fluid, I had no idea that any seeds were so resistant to its action. For instance, L u p in u s a 1 b u s immersed in it for five hours and fifteen minutes still gave 52 per cent of good seedlings. Up to about two hours immersion L u p in $\mathrm{s}$ a $1 \mathrm{bus}$ gave, in practically every case, about 100 per cent of good seedlings. P i s u m s a t i v u m was also more resistant than was expected. After six minutes exposure to this fluid, 88 per cent of good seedlings were obtained; and after forty-five minutes immersion, the yield was still 76 per cent. Tritic $\mathrm{m}$ v u l g a re and $\mathrm{H} \mathrm{or} \mathrm{de} \mathrm{m}$ v $u l g$ a $\mathrm{r}$ e were found to be rather sensitive to the action of cleaning fluid. After seven minutes exposure, the former yielded only 28 per cent of good seedlings; while after ten minutes exposure, the latter yielded 44 per cent 
of good seedlings. $\mathrm{Z}$ e a $\mathrm{m}$ a $\mathrm{y} \mathrm{s}$ was found to be more resistant than $\mathrm{T} r \mathrm{i} \mathrm{i}$ c u $\mathrm{m}$ or Hordeum but not so resistant as $\mathrm{L} u$ pinus or $\mathrm{P}$ is $u \mathrm{~m}$.

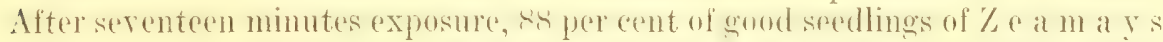
were obtained; but from there on the pereentage of gemination fell rapbily. Thus after twenty minutes exposure, only 16 per cent of good seodlings were obtained; and, after twenty-five minutes exposure, only 4 per cent. S i n a $p$ is a $1 \mathrm{~b}$ a was slightly more resistant than $\mathrm{T}$ rit i c u m. After a ten minutes exposure, 5ti prer cent of good serellings vere ohtained. The foregoing tests and the following were made in a temperature of $20^{\circ}$ to $22^{\circ} \mathrm{C}$.

The second disinfectant employed was mereuric chloride. To prevent the adhesion of air-bubhles, the seeds wexe first dipped in 70 per cent alcohol, then thoroughly rinsed in water to remove the aleohol and finally placed in the mercuric choride. The concentration of merenric chloride employed varied from one gram of mercuric chloride in one thousand ce. of water to one gram in fifteen ce. of water. When $L$ u $p$ in $u s$ a 1 b u s was immersed in a one to two hundred and fifty solution for fifty minutes, 100 per cent of good seedlings were still obtained. Beyond that concentration and length of immersion the pereentage steadily deceased, until, at a concentration of one to fifteen for one hour and fiftecon minutes, it had dropped to s.) pere cont. For $\mathrm{P}$ is $\mathrm{um}$ s a t i v u $\mathrm{m}$ a one to five hundred solution only was used. The vield of good seedlings, after a thirty minute immersion, was ss per cent; and after a fifty minute immersion it was 64 per cent. 'T r i t i c u $\mathrm{m} \mathrm{v}$ u lgare was found to be much more semsitive to meremice chloride than either L u p in us or Pisum. After a thirty-minute immersion in a one to five-hundred solution, only 52 per cent of good seedlings were obtained; while, after an immersion of ten minutes, the yield was 92 per cent. $\mathrm{H} 0 \mathrm{r}$ de u $\mathrm{m} \mathrm{vl} \mathrm{g}$ are was found to be extremely sensitive to the action of mercuric chloride. Even after an immersion of only two minutes in a one to one thousand solution, the yield of good serdlings was only tio per cent. $\mathrm{Z}$ e a $\mathrm{m}$ a $\mathrm{y} \mathrm{s}$ was found to be more resistant to the action of mercuric chloride than Triticum. After an immersion of thirty mimutes in a one to fire humdred solution, the yield of good seedlings was 68 per cent; but in a one to two hundred and fifty solution, after the same leneth of time, the vicld was only 20 per cent. Sin a p is a 1 b a, after an immersion of ten minutes, in a one to one thousand solution yielded 76 per eent of word seedlings. Then the concontration was increased to one to five hundred and the time to thirty minutes, the pereentage dropped to eight. Fefore placoing in the germinator, the seeds were thoroughly washed in several changes of water for about an hour.

The third disinfectant employed was peroxide of hydrogen. The commercial peroxide was used, and in no instance was it diluted. The length of time the seeds were immersed in it varied from ten minutes to nine hours. Is u p in u s a $1 \mathrm{bus}$, immersed for an hour, still yielded 100 per cent of good seedlings; when immersed for nine hours, the yield had dropped to bo pere cent. After an immersion of thirty minutes, $\mathrm{P}$ is $u \mathrm{~m}$ s a $\mathrm{t}$ iv u $\mathrm{m}$ yielded 100 per cent, but after one hour, the yield was only 52 per cent. T r i t i c u m v u lgare, after being immersed for an hour, yiclded 84 per cent of good seedlings. Horde $\mathrm{m} \mathrm{v} u \mathrm{lg}$ a $\mathrm{re}$ was found to be very sensitive to the action of the peroxide. After an immersion of only ten minutes, the yield was 48 per cent, but when immersed for an hour the vicld fell to 12 per cent. After an immersion of nine hours, $\mathrm{Z}$ e a $\mathrm{m}$ a y s yielded 76 per cent of good 
seedlings. Sin a $p$ is a 1 b a was found to be more sensitive, since, after an hour's immersion, it yielded 64 per cent.

The fourtl disinfectant employed was potassium dichromate. The concentrations employed varied from N/2 to $\mathrm{N} / 1000$; and the length of immersion varied from fifteen minutes to an hour. As in the case of the other disinfectants, the yield of $\mathrm{L} u p$ i $u$ u a 1 b u s was relatively high, since the riedd was still $8+$ per cent aftrer an immersion of one hour in an $\mathrm{X} / 2$ solution. The highest concentration found practicable, in the case of $\mathrm{P}$ is u $\mathrm{m}$ s a $\mathrm{t} \mathrm{i}$ r u $\mathrm{m}$ was $\mathrm{N} / 50$. After being immersed in this for an hour, the yield was 72 per cent. The same concentration could be used for Tritic u $\mathrm{m} \mathrm{v} \mathrm{u} \mathrm{l}$ g a re. After a twenty-minute immersion, the yield was 88 per cent. Very poor results were obtained with $\mathrm{H}$ orde $\mathrm{m} \mathrm{m}$ v l g a re, since a twenty minute immersion in a solution as dilute as $\mathrm{T} / 1000$ vielded only 40 per eent of erood seedliness. The concentration most useful in the case of 7 a a II a y s was found to be $\mathrm{N} / 10$. The yield after an immersion of one hour, was still 56 per cent. N/25 was better adapted to $\mathrm{S}$ i $n$ a $p$ is a 1 b a than any other concentration. Alter a twenty minute immersion. the yield of gond seedlings was 88 per cent.

Ammonium persulphate was next used. The highest concentration used was one gram of the persulphate in three ce. of water the lowest concentration was one gam in one thousand ece of watre. The periods of immersion varied from thirty minutes to four hours and a half. The longer periods were used in the case of $\mathrm{L} u \mathrm{p}$ in us a $1 \mathrm{~b} u \mathrm{~s}$ only. The following concentrations were found to be best adapted to the different seeds; one to three for $\mathrm{L} u \mathrm{p}$ in u s a $1 \mathrm{~b} u \mathrm{~s}$, one to two hundred and fifty for $\mathrm{P}$ is u $\mathrm{m}$ s a $\mathrm{t}$ i -

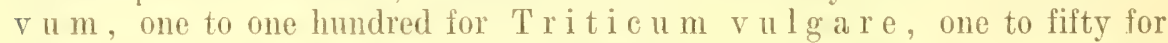
$\mathrm{Ze}$ a $\mathrm{mays}$, and one to five hundred for $\mathrm{S}$ in a p is a $1 \mathrm{~b}$ a. When L u p in us a 1 b a was immersed for four hours and a half in a one to three solution, the yiedd of good seedlings was still so per cent. Yo higher concentration could be obtained, since that was a saturated solution. The lowest concentration, one to one thousand, was used for Hordeum vulgare only. When $\mathrm{Horde}$ m v u g a re was immersed for only ten minutes, the yield was only 28 per cent.

Since the halegens are good disinferetants, it was thought best to include at least one of them in these experiments. For this purpose bromine water was taken. The plain bromine water, userl as a reagent in the chemical laboratory, was used. The bromine water was used full strength, as received from the chemical laboratory: and in dilutions as low ats one part of lommine water to five thousand parts of water. The lighest concentration was used for L up in u s a lous only, and the lowest for $\mathrm{H}$ orde $u \mathrm{~m} \mathrm{vulgare}$ only. L u p in $u \mathrm{~s}$ a $1 \mathrm{~b}$ u s immersed for an hour and forty minutes yielded 100 per cent of good seedlings. Then immored for six hours the vield was 44 per cent. P is u m s t i v u m, immersed for ten minutes in a one to fifty solution, gave a yield of 64 per cent. The behavior of $\mathrm{T}$ r i t i c u m v u lgare, at the different concentrations, was practically the same as $\mathrm{P}$ is $\mathrm{um}$ s a t i v u m, except that in the lower concentrations T $\mathrm{T}$ it i c u m gave a somewhat higher percentage of good seedlings $\mathrm{H}$ orde u m v u l$\mathrm{g}$ a re was so sensitive that it had to be thrown out. In a concentration of one to five thousand in which it was immersed for only ten minutes, the seeds were so much damaged that the yodd of gond seedlings was only jo per eent. 
Concentrations of one to fifty, one to one hundred, and one to two hundred and fifty were used for $\mathrm{Z}$ e a $\mathrm{m}$ a y s. The lenght of immersion varied from ten to fifty minutes. The pereentare yidd varied from forty-four to serentytwo. Although higher concentrations were tried for $\mathrm{S}$ in a p is a $1 \mathrm{~b}$ a , one to five hundred was found to be the most suitable. After ten minutes immersion in this solution, the pereentage of gond sordings was ninety-two: after fifty minutes immersion the percentage was sixty.

The last disinfectant used was formaldehyde gas. Forty per cent formaldehyde was put in an open vessel placed on at glas plate, on which the seeds were also placed. The whole was then covered with a bell-jar, the edge of which, where it came in contact with the glass plate, was given a coat of vaselime so as to malie the chamber air-tight. Boih dry seeds and seeds soaked for five minutes in water were used. The dry seeds of $L$ u p in u s a $1 \mathrm{~b} u \mathrm{~s}$ had to be exposed for an hour and forty-five minutes before the armination pereentage dropped; and then it had dropped only to ninety-six. When the soaked seeds had been expesed for forty-five minutes, the oemination pereentage dropped to ninetytwo. Beyond these periods, the vitality of the seeds stradily decreated, that of the soalied seeds becoming zero after severn hours, while the dry seeds retained their vitality an hour or two longer. The relative effect of the gas on dry and wet seeds is clearly brought out in the case of $\mathrm{P}$ is $u \mathrm{~m}$ s a t i vu m. Dry seeds, exposed for fifteen minutes yielded tit per cent of good seedlings: while the soaked seeds violded only es prer cent. To obtain a yield of 64 per cent in the case of the wet seeds, they could be exposed for two minutes only. After a twenty-five minute exposure of the wet seeds, only 16 per cent of good seedlings were obtained; while the dry seeds, exposed for an hour, still yielded 36 per cent. Trit i c u m v u l$\mathrm{g}$ a $\mathrm{re}$ was found to be less sensitive to formaldehyde than $\mathrm{P}$ is u $\mathrm{m}$ s a $\mathrm{t}$ i v u m. After an exposure of fifteen minutes, the dry seeds yielded 92 per cent of good seedlings; while the soaked seeds still yielded 52 per cent. A tenminute exposure of the wet seeds, also gave 92 per cent. H o r d e $\mathrm{um} \mathrm{v} \mathrm{u} \mathrm{l-}$ $\mathrm{g}$ are was found to be extremely sensitive to formaldehyde gas. A fifteenminute exposure of the dry seeds and a five minute exposure of the wet seeds gave a germination percentage of only twelve. The dry seeds of $\mathrm{Z}$ e a $\mathrm{m}$ a y s were considerably more resistant than Triticum; the soaked seeds only slightly so. Dry seeds, pxposed for an hour, rielded so per cent of enoud

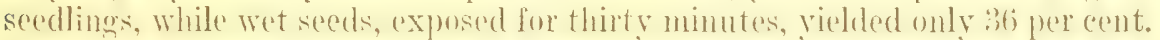
The dry seeds of $\mathrm{S}$ in a $\mathrm{p}$ is a $1 \mathrm{~b}$ a could be exposed three times as long as the soaked seeds, and they still showed an wyual vitality. Thus dry seeds exposed for forty-five minutsis, and soaked serels, exposed for fiftern minutes, both yielded 40 per cent of good seedlings. Dry seeds, exposed for thirty minutes, vielded bs pere cent; while wet seeds, exposed for the sime length of time, yielded only 24 per cent.

In the first column of Table I are given the names of the seeds; in the second columm the disinfectants; in the third column the concentrations best suited for the different kinds of sexds; in the fourth columm the length of immersion of the secels in the disinfectants which would still give a fatr percentage of good seedlings: in the fifth enlumen the germination pereentage; and in the sixth eolumn are given the results, as tested with the apparatus (sec plate), of the action of the different disinfectants on the fungi and haceteria on the seeds. As can be seen by rumning over this column, only nine lots out of forty were found to be sterile, each lot being treated differently. 
$\mathrm{T}$ a b 1 e $\mathrm{I}$.

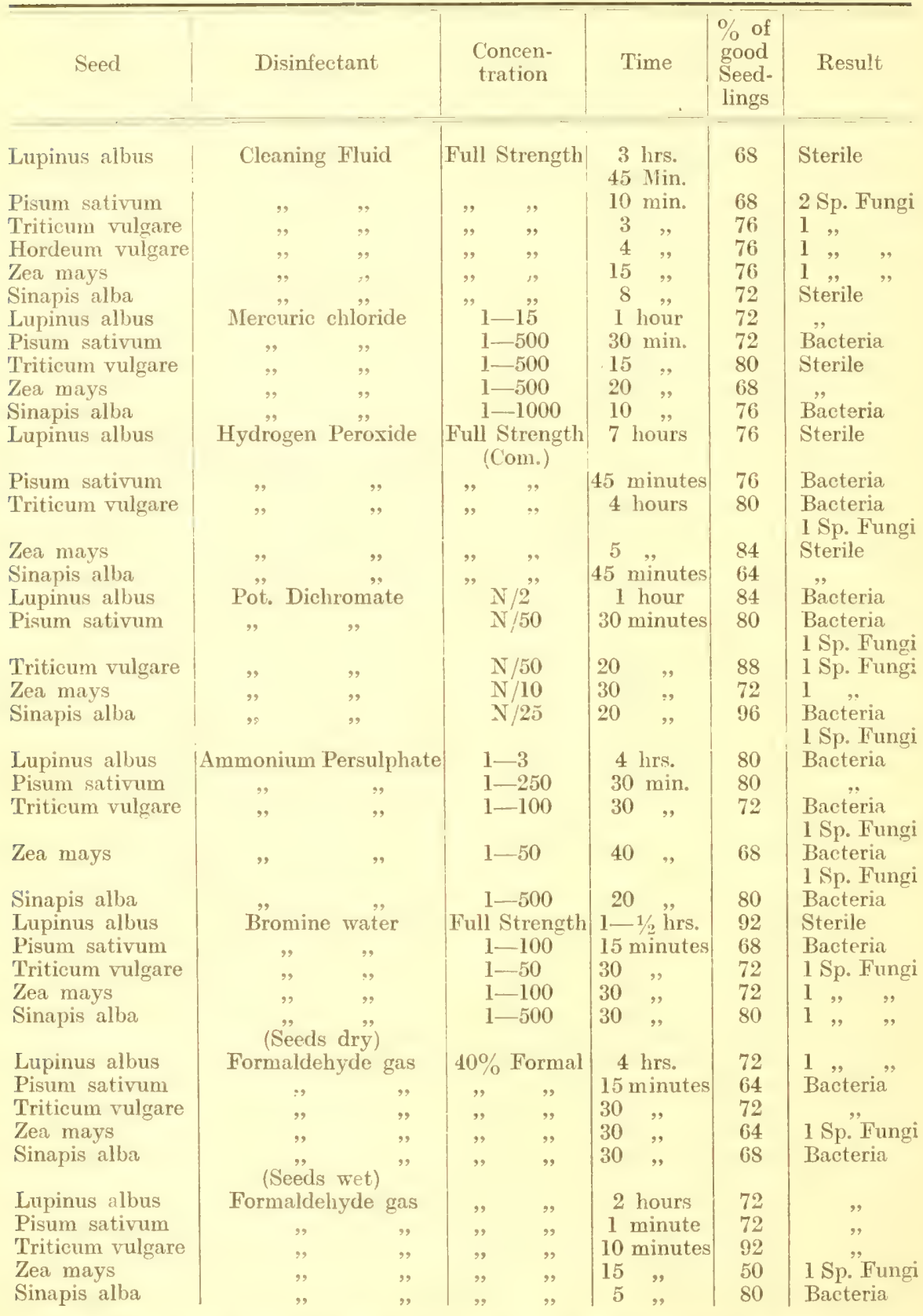

I was not at all certain that the nine lots. which showed no contamination in the foregoing experiments, would show the same results again, if treated in a similar manner. For this purpose three lots of each were set up, treated as before and allowed to incubate. The results are given in table II. 
Four of the nine failed to show up sterile three times in succession, while five remained sterile after incubation in all three tests. This means that apparently only five lots out of the original forty could be depended mpon as being sterile when treated aceording to Table $\mathrm{T}$. Of these five lots, three were L u p in us a $1 \mathrm{bus}$, and two were $\mathrm{S}$ in a p is alba.

Table 11 .

\begin{tabular}{|c|c|c|c|c|c|c|}
\hline Seed & Disinfectant & $\begin{array}{c}\text { Con- } \\
\text { centration }\end{array}$ & Time. & $\begin{array}{l}\text { First } \\
\text { Lot }\end{array}$ & $\begin{array}{l}\text { Sterility } \\
\text { Second } \\
\text { Lot }\end{array}$ & $\begin{array}{l}\text { Third } \\
\text { Lot }\end{array}$ \\
\hline $\begin{array}{l}\text { Lupinus albus } \\
\text { Sinapis alba }\end{array}$ & $\begin{array}{l}\text { Cleaning } \\
\text { Fluid } \\
\text { Cleaning }\end{array}$ & Full Strength & 3 hrs. 45 min. & Sterile & Sterile & Sterile \\
\hline Lupinus albus & $\begin{array}{l}\text { Fluid } \\
\text { Mercuric } \\
\text { Chloride }\end{array}$ & $\begin{array}{r}", \\
1-15\end{array}$ & $\begin{array}{l}8 \text { minutes } \\
1 \text { hour }\end{array}$ & ", & $"$ & ", \\
\hline Triticum vulgare & $\begin{array}{l}\text { Mercuric } \\
\text { Chloride }\end{array}$ & $1-500$ & 15 minutes & , & Dacteria & Sterile \\
\hline Zea mays & $\begin{array}{l}\text { Mercuric } \\
\text { Chloride } \\
\text { Hydrogen }\end{array}$ & $1-500$ & 20 minutes & , & Sterile & Fungus \\
\hline $\begin{array}{l}\text { Lupinus alous } \\
\text { Zea mays }\end{array}$ & $\begin{array}{l}\text { Hydrogen } \\
\text { Peroxide } \\
\text { Hydrogen }\end{array}$ & Full Strength & 7 hours & , & D & Sterile \\
\hline Sinapis alba & $\begin{array}{l}\text { Peroxide } \\
\text { Hydrogen } \\
\text { Peroxide }\end{array}$ & ", & $\begin{array}{l}5 \text { hours } \\
45 \text { minutes }\end{array}$ & " & Bacteria & $\begin{array}{l}\text { Fungus } \\
\text { Sterile }\end{array}$ \\
\hline Lupinus albus & $\begin{array}{l}\text { Bromine } \\
\text { water }\end{array}$ &,$\quad$, & 1-1/2 hours & & & \\
\hline
\end{tabular}

Since mereuric chloride is recognized as the most valuable desinfectant we have, it was thought hest to test for sterility three lots each of the seedi used in these experiments. The length of time the seods were immersed and the concentrations are those determined upun in the germination tests with mercuric chloride. biy reference to Table 1, the eremination may be found. The results of these three tests are given in columms thres, four and fire. of Table Ill. Nome of these cultures showed growths of fungi or bacteria three times in succession and none were sterile three times in succession. The results in this case were rather disappointing, since they show that mercoric chloride cannot be depended umon to give sterile seeds in every case. The more so, since the aim was to test kinds of seeds fairly representativi of all seeds likely to be used for laboratory purposes.

Ta ble III.

Mercuric Chloride.

\begin{tabular}{|c|c|c|c|c|}
\hline Seed & First T'rial & Second Trial & Third Trial & $\begin{array}{c}\text { Concentration } \\
\text { and time. }\end{array}$ \\
\hline $\begin{array}{l}\text { Lupinus albus } \\
\text { Pisum sativum } \\
\text { Triticum vulgare } \\
\text { Zea mays } \\
\text { Sinapis alba }\end{array}$ & $\begin{array}{l}\text { Sterile } \\
\text { Bacteria } \\
\text { Sterile } \\
\text { Sterile } \\
\text { Bacteria }\end{array}$ & $\begin{array}{l}\text { Bacteria } \\
\text { Sterile } \\
\text { Bacteria } \\
\text { Sterile } \\
\text { Bacteria }\end{array}$ & $\begin{array}{l}\text { Bacteria } \\
\text { Sterile } \\
\text { Sterile } \\
\text { Fungus } \\
\text { Sterile }\end{array}$ & 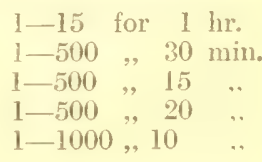 \\
\hline
\end{tabular}

Since the decisive failure to obtain sterile seeds, shown in Tables I, II and $I I I$, might reasonably be expected to make the technique appear open 
to criticism, to say the least, it was thought advisable to set up a series of control cultures by means of the apparatus. After the apparatus had been sterilized in the antoclave, it was attached to the aspirator and air was drawn throught he filter plugs for at least fire minutes to test them and at the same time to test the rubinel commections. No seeds or disinfectant were placed in D. Water was then drawn from flask A into flask D. After this a small guantity of agar culture medium was drawn into flask D in the usual manner. Flask D was then taken out and set aside to incubate, as in the experimental cases. The idea was to test the apparatus by using it as nearly as possible in the same way as when seeds and disinfectants were present. As a matter of fact. I took less pains in the control experiments to see that the joints wore perfectly tight than I did when I tested seeds. The fact that flask D was not opened during these control experiments camot be held as an objection, since any chance contamination, when the seeds were placed in flask D, is reached by shaking up the disinfectant so as to thoroughly reach every part that might have become contaminated. If the chance spores were able to survive that, then it is manifestly impossible to kill those on the seeds, and the point is proven either way. The only place the disinfectant, when the seeds are treated, does not reach is the inside of the small glass tube connecting 1 and D). It was sterile when D was opened to admit the seeds and disinfectant and, during the briof period of time that $D$ remained open, the mouth of the tube was directed downard, so no spores could drop in and none could he drawn in, sinee there was no draft into it. Besides, if any contamination could come from this somre, in the case of the seeds, it would have appeared in the controls as well. Iot none of the controls showed any contamination. The conchusion sems irresistable that the contamination must have come from the seeds. Twenty controls were used.

\section{Discussion.}

The following three points will he considered in the discussion of results:

T. Some causes of failure to obtain seeds free from fungi and bacteria by disinfection methods.

11. Other methods that may be suecessful for obtaining seedlings free from fungi and bacteria.

III. Some reasons why much of the work on seed-sterilization is open to criticism.

\section{I.}

In view of the fact that out of six species of seed treated only two kinds, $\mathrm{Lup}$ in us a $1 \mathrm{bus}$ and $\mathrm{P}$ is um sativum, gave germinable seeds, free from fungi and bacteria, it is only reasonable to look for some cause or causes to explain this failure. The foregoing results are the more striking, since, out of the seven disinfectants used, only three were effective in securing seedlings free from bacteria and funci, in the case of $\mathrm{L} u$ p i n us a l bus and only two in the case of $\mathrm{S}$ i $n$ a $p$ is a 1 h a. The cause of failure to obtain the desired result is at least three-fold. First, the condition of the contamimating oreanisms or their environment may make it impossible to destror them, without destroving also the germ of the seed. Second, the disinfectants, in a criven case, inay act merely as antiseptics, producing only apparently sterilized seeds. Third, the required concentration of the disinfectant and the required length of immersion may differ from those outlined in the prece. ding experiments. 
Since conditions unfavorable for growth favor sporulation in bacteria, it is probable that the bacteria are found on the seeds as spores. As is well known, a bacterial spore is exceedingly more difficult to kill than a vegetating form. Add to this the protection the contaminating oreanisms enjoy:

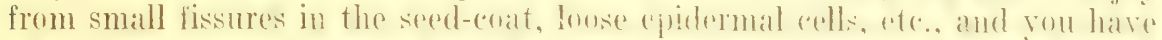
a combination which aids the inferetiog orentisms. but which gives little if any protection to the extremely sensitive seed-embryo. No v y and W a it e's ('os) work on room disinfection eonctusively shows that organisms, which may be quite readily destroyed when freely exposed to the desinfectant, will survive for hours, if treated in small masses, or if protected by small amounts of foreign substances. There is no bacterium known that can be immersed in a saturated solution of mereurice chloride for an hour and survive. Yet I found that bacteria survived that treatment when found on seeds. Protection of the oreanism can be the only explanation here. For this reason, the F ürbringer method might be useful in treating seeds. The value of this method lies in the prediminary use of aleohnl. The alcohol dissolves and elears away from the seed-coat substaness that interfere with the action of the disinfectant which follows it.

Not only may the contaminating organisms be protected by fissures in the seed-ceat, debris, ote., but they may be found within the seed-enat. This is especially the case with fungi. To explain the overwintering of the rust on wheat, Eriksson formulated his Mycoplasm Theory. He claims that the fungus is present in the host colls as naked motoplasm, which could be distinguished from the proteplisin of the hos hy rareful staining. Bo olley and Pritchard ('95) say that what Eriksson saw in the cells of the seeds were the haustoria of the parasite. The Mycoplasm theory does not seem necessary to account for the fact. Bolley and P r it chard ('05) have shown that the mycelimm of wheat mist penethates the seed-coat and is thus carried over winter. Han $\mathrm{nig}$ ('08), working on Lolium t e mule $\mathrm{ntum}$, found a mycelium inside the seed-coat, growing over the aleurone layer. Freem an ('04) also working on Lolium t e mule n tum, found that in some cases the mycelium had even penetrated the embryo. W b e $\mathrm{z}$ el ('06), working on beans, found that a fungus myecelium penetrated not only the pod but also the seed-coat and cotyledons. My failure to remove fungi from seeds must, it seems to me, be referred to a similar cause. It must be evident that when the funcus mycelium is within the seed-coat, as Hannig ('08) found in Lolium te m u lentum, or with the embryo as Whetzel ('06) found in the bean, or as Free m a $n$ found in the Lolium temulentum, it becomes hopeless to expect to kill it without at the same time killing the seed.

Of course the cases enumerated above were all instances of parasitic fungi. But, if they show anything, they show that mere superficial disinfection will not avail in all eases. However, a saprophyte may become a facultative parasite. It seems permissable to assume that many of the ordinary fungi found on seeds in the laboratory behave as facultative parasites. That they have penetrated the seed-coat to a greater or less depth cannot be doubted. I found a striking confirmation of this fact in my work with chaning fluid. L u p in $u$ s a lbus and $S$ in a p is a 1 ba were found to be free from infecting organisms of any kind. $\mathrm{P}$ is $\mathrm{um}$ s a tivu $\mathrm{m}$, Triticu $\mathrm{T}$ vulgare, Hordeum vulgare and Zea mays were found to be infected with fungi. after they hat heen treated with cleaning fluid till 
nearly all of the seed-coat or fruit-coat had been destroyed. Pis a m s a t i $\mathrm{v} u \mathrm{~m}$ and $\mathrm{Z}$ e a $\mathrm{m}$ a $\mathrm{ys}$ even had two species of fungi growing on them after treatment with cleaning fluid. On nome of these six lots did bacteria develope. These facts seem impossible of explanation, unless we assume that the fungi had penetrated the seeds.

The failure to obtain seeds free from contamination may also be due to the fact that the disinfectant acts as an antiseptic, which inhibis bacteria but allows them to develope when it is removed. This brings up the question: That is the difference between bactericidal and antiseptic action? Probably the correct answer is that it is merely a matter of degres. st te r n b e r g ('01) makes the following distinction: "All disinfectants are also antisepties, for agents which destroy the vitality of the bactoria of putrefaction arrest the putrefactive process: and these agents, in less amount than is required to completely sterilize, arrest growth and thus act as antisepties. But all antisepties are not gernicides." P a 11 l ('01) also says that inhibition, which oceurs when a solution of one to one million of mercuric chloride is used, and sterilization are merely a matter of degree. $\mathrm{Park}(05)^{\prime}$, in his work on "Pathogenic Bacteria and Protozod", reconenized the following four degrees: Attenuation, antisepsis, incomplete sterilization and disinfection. Antisepsis has not been recoenized at all in work on seed sterjization, and not as much as it deserves in other work. It is rery probable that in antisepsis lies the ker to the problem of ohtaining seceds fiee from bacteria and fungi, or rather. sereds on which the fungi and bacteria are inhibited from dereloping and multiplying. If hy a dilute solution which will not harm the seeds, we can frevent the organisms from dereloping, the result, as far as the bacteria and fungi are concerned, will be the same as if the seeds were actually streilized. Intisepsis is asily mistaken fur disinfection, as S te e $n$ b e r g ('(b) points out: " ()ne to ten thousand solution of merenric chloride destroyed the spores of B. anthracis and B. subtilis in two hours. More recent rxperiments show that failure to grow in culture solntions cannot lie areepted as evidener of the destruetion of vitality in the cases of spores exposed to the action of this agent, muless due precautions are talien to exclude the restraining influence of the small ammunt of mereurice chloride." G e p pe e t ('89), working on B. a $n \mathrm{t}$ h $\mathrm{r}$ a $\mathrm{c}$ is, found that pieces of silk thread, soaked in a surpension of hateteria and then dried could he rendered apparently sterile by leavine them for ten minutes in a one to one thousand solution of merevire whloride. Placed in henthlon and incubated for a sufficient length of time, no colonies developed. Piut, if similar threads were weed in a similar mammer, but treated with ammonium sulphicle before being placed in the boullon, fop per found that abundant colonies developed. The ammonium sulphide roats (hemically with the mereuric chloride breaking up that powerful poison and forming the compounds ammonium chloride and mercurous sulphide. Sereral colonies were found to develope even in cases when the pieces of thread had been treated with mercuric chloride for half an hour. The objection that the silk threads afford proteretion to the baeteria might reasonahly be raised here. But (i c p pe re tepeated his work with bacterial suspensions dried an over-glasses, with similar results. These facts show that we are obliged to rologate many cases of so-called disinfection to antisepsis. My own work with mercuric chloride on seeds also seemed to indicate that the actinn was largely antiseptic. A marked difference was observed, when the seeds were merely in two or three changes of sterile water 
and when they were washed for an hour in ten or twelre changes. Mlso a weak solution acting for a short time, but not so thoroughly washed off, was more effective in producing antisepsis than a strong sulution, ateting for a longer time and not so thoroughly washed off. At mo time, when I had the pleasure of discussing the question of antisepsis with Dr. I o r y, of the bacteriological laboratory of this university, he laid special emphasis on the size of the platinum loop) with which inoculations were made from bacterial suspensions, to which a definite amount of mereuric chloride had bren added ats an antiseptic. He found, for instance, that enough merenic chloride might be transferred on a $2 m m$. loop, when a tube of homillon was inoculated from such a suspension, to inhibit the development of bacteria. A 1 mm. loop, on the other hand, might carry over insufficient mercuric chloride to produce such results. Or arain, if, after thoronghly mixing the bonillon in the tube inoculated with a $2 \mathrm{~mm}$. loop, he inoculated a second tube of bouillon with a loopful of the first he would get a growth of bateteria in the second tube, while the first remained clear.

The last topic to be considered under the head of causes of failure to obtain seeds free from contaminating organisms is the matter of the required concentration of the disinfectant and the leneth of time the sereds should be immersed in it to produce the desired results. In other words: Is it, for instance, better to immerse a seed for a short time in a strong, or, fur a longer time, in a weaker solution? There is always a possibility that this would lead us nowhere. Still there is also the possibility that concentrations and periuds of immersion play a larger role in the relative effece on sereds and their infecting organisms than we now suppose. To determine this point is bevond the scope of the present paper. It would recpuire a long series of experiments, in which only one disinfocetant is used and the results of which are constantly checked by some such apparatus as was designed for the seeond series of experiments in this paper. Some work done in this lathoratory on imbibition hy seeds showed that about so pereent of the water absorlued by the sered was absorbed during the first live minutes. Thus it wonld sem that the more

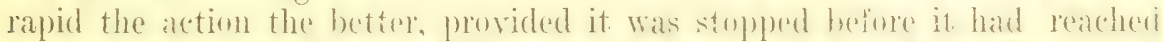

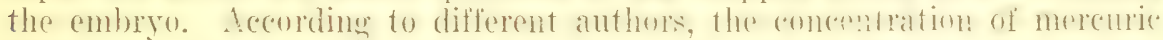
chloride to be employed varied from 0.1 percent to 0.5 percent, and the recommended perion of immersion from two or thre mintes to half an hoar. No rule can be laid down, since one species of seed is so much more resistant thatn another. Fren dilferent lots of the same kind of serel will rary so much that the treatment which will kill one sample will not injum another ample. For instance, K e hler (1904) immersed Triticum rulgare in a one to five hundred solution of mercuric chloride for half an hour and obtained 99.5 pereent af good seedlines. When I tried to duplicate his results.

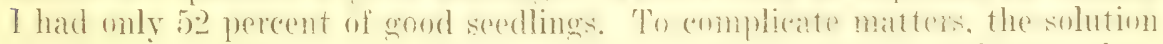
does not keep the same concentration during the entire experiment, since

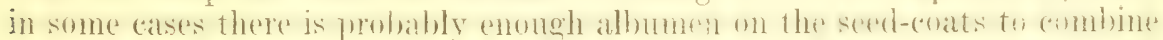
with most of the arailable mereury, forming an insthible alhominate. All of this goes to show how difficult it is, in work of this kind, to duplicate results. According to $\mathrm{No}$ V y and $\mathrm{W}$ a it e (1895): , there is no chemic disinfectant which will invariably vield the same ralts reandlest of the oreanism to be acted upon and the surroundings or enviromments of that organism". ()n comparing the results of ofher workers with rach other and with my own, J an convinced that in seed sterilization this holds mominently true. In 
examination of the work of Pam el (1899) shows what part the seedcoat plars in the rariability of the results obtained in two sets of experiments. Thickness, structure and composition, each adds something to the sumtotal of the results obtained. In this comnection, see note on Browns paper at the end of this paper, especially with reference to the extreme sensitiveness of Hordeim noted in the preceding pages. It is not possible here to enter into a full incuiry into and a complete discussion of the causes of the difference observed in the relative sensitiveness of the different seeds. To do that we should be obliged to devote too much space to the comparative histology of the seed-coats of the different seeds employed.

II.

There are three methods, other than disinfection, which should be discussed here. The first of these is excision of the embryo. This method has been employed especially by men worling on endospermic respiration, respiration of the ('mb)ryo, ite. It seems cuite likely that sterile seedlings might be ohtained by this method. But the conditions must be just right. In the first place, the embryo must be uninfected. When the fungus has penetrated it, excision of the embryo is naturally useless. Further it requires the most eareful and delicate technique to obtain any results whatsoever bo this method. How easily can an infecting germ be carried hy the linife to the embryo, when the purts covering it are removed! If the seed-coat can be so thoroughly sterilized that there is no danger of infecting the kinife, there can be no necessity for excising the embryo.

Another method is that adopted by $\mathrm{Cz}$ a p e $\mathrm{k}(1896)$ for $\mathrm{Z}$ e a $\mathrm{m}$ a y s. The dry grains were first polished by means of a dry, stiff brush, till no more scales came off; then they were thoroughly scrubhed for several minutes with warm water, soap and a brush; then they were rinsed in several changes of warm sterile water; and finally they were immersed for two or three minutes in a one pereent solution of mercuric chloride. The seeds were then put in the germinator without first rinsing them. The main objection to this method is its limited applicability. It is obvinusly impossible to treat all seeds that war. Some seeds are too small, like Sinapis: or too light, like many of the eramineas: while the surface enfiguration, like that of T r it i c u m, precludes such a procedure. Another aljection was the comparatively laree amount of mercurie chloride that was allowed to remain on the secods, more than cuough to cause antisepsis. To definite conclusion can he reached without a series of experiments with that end in riew, as to the sterility or non-sterility of seeds thus treated.

A third method, employed by $\mathrm{Harris}$ on and Barlow (1907), may be called the selection method. About the only value I can see in this method is the elinination of infected seeds. The method they followed is as follows: One to three seeds were dropped in a test-tube containing about 3 ce. of boiling water. The tubes were immediately eooled and set aside. They were tilted so that the secds were only half covered with water. Those tubes in which the water became clondy, showing the presence of bacteria, were rejected. The seedlings in the unhes, in which the liquid remained clear, were then planted lis means of sterile forceps in a sterile medium in E r l e n$\mathrm{m}$ e y e $\mathrm{r}$ flasks. These flasks were then set aside for four or five days. At the end of that time, any cultures showing contamination were again eliminated. The writers do not say what pereentage of the original seeds were 
left. It certainly can not have been large. It is also doubthul that the hot water acting for so short a time had any effect.

\section{III.}

In judging the value of previous work done on seret strilization, it slonuld be borne in mind that practically all that has been done was merely incidental. The author wats, as a general lule, woling on some moblem for which it was advantageous to have sterile seedlings. Thus we find in papers on different pieces of work, tucked away here and there, a paragraph on seed sterilization. In practically all instances there an be no douht that sulficient of the disinfectant remained to inhibit the derelomment of such organisms as might be present. 'This point has been more fully disensed above. But what seems most remarkable is the lack of adequate proof that the seeds were actually sterile. Thus $\mathrm{NeI}$ s o n (1907) treating seed-potatoes for Oospora scabies, immersed them for an hour and a half in a one to one thousand solution of mereuric rhloride, without any subseguent washing. They were allowed to dry and were then planted. Who shall say how long a goodly amount of mercuric chloride clung to the potatoes?. 'The same objection holds in regard to $\mathrm{C} z$ a p e ks (1896) work. S t e wa r d (1908) claims that his seedlings were sterile at the che of fourteren or sixteen days. The only proof he offers is the fact that he inoculated a tube of houillon with a litkle of the material seraved from as seedline with a platimum needle. The prevailing tendeney seems to he a too great willingness to assume that the seedlings were sterile. Ko h le r (1904) obtained some striking results. His technique, however, is not above criticism. It seems to me extremely doubtful that a rubher tube call be sterilized by boiling for half an hour on thee successive days the water in the flask to which it is attached. The more so when the flask is closed hy means of a cotton plug around the tube entering it. This tuhe is withdrawn to ahove the water level churing the boiling and again pushed down after it has heen flamed. Finally the seeds are taken out of the receptacle and transferred to flasks of culture medium $\mathrm{through}$ the a ir. The apparatus should have been constructed in such a way as to prevent the seeds from coming in contact with the air at any time until the incubation was completed. And yet, for all that, $\mathrm{K}$ e h le $\mathrm{r}$ claimed to have obtained sterile seeds in every case. K e h l e r does not speak of thorough and poolonged washing. That probably explains his results. Since $\mathrm{Ke} \mathrm{hler}$ mentions Gep pert's work with ammonium sulphide, it seems almost inexplicable that he did not eheck up his (iwn results by means of it. If he had done so and no oreanisms had dereloped, it would be ronclusive pronf of the correctuess of his anclusions. Tow, it seems to me, we are justified in doubting his conclusions.

\section{Summary and Conclusions.}

1. For certain physiological experiments, seeds free from bacteria and fungi are essential. Since there was no convincing evidence at hand that any of the methods used by othersind isinfecting seeds, wereabsolutely reliable, this work was undertaken to supply, if possible, thateridence, or toprove that the methods generally employed are inade- 
quate to furnish seeds free from contaminating or g a $n$ is $\mathrm{ms}$.

2. Lots of twenty-five each of the following species of seedswere used in the foregoing experiments: Lupinus a lous, Pisum sativum, Triticum vulgare, Hordeum vulgare, Zea mays, and Sinapis alba. Similar lots in each case were treated for varying lengths of time with each of the following disinfectants: cleaning fluid, mercuric chloride, hydrogen peroxide, potassium dichromate, ammonium persulphate, bromine water, formaldehyde gas on dry seeds and formaldehydegas on seeds soaked in water for five minutes. In the first series of experiments the efforts were directed toward determining the length of time each kind of seeds could be left in each one of the disinfectants, and still yield 70 percent or 80 percent of good seedlings. Afterthis had beendetermined, a second series of experiments was used to determine the effect of the different disinfectants on the fungi, and bacteria, after the seeds had been in the disinfectant for such a length of timeas would still permit a fair percentage of seeds to germinate.

3. The results obtained are rather strikingly opposed to those of other workers. Whenthe action of the disinfectant was stopped at the point where stilla fairpercentageofthe seeds weregerminable, the results showed quite uniformly that the contam inating organisms had not been destroyed, exceptin a few instances noted below. Of the fortyeight lots tested, only two lots of $\mathrm{sinap}$ is a 1 ba and three lots of Lupinus albus werefree from bacteria and fungi. The $0 \mathrm{nly}$ dis infectants which removed a 11 contaminating organisms from these seeds were cleaning fluid and peroxide of hydrogen. Bromine water was also sucessful in the case of Lupinus albus. The foregoingexperiments todetermine the action of the disinfectants on fungi and bacteria weresetup with a specially constructed apparatus, which prevented outside contamination.

4. In view of the results above, it was deemed best to set up twenty control preparations. They wereset up in a manersimilar to those above, except that no seeds or disinfectant were used. All of the control preparations were sterile at the end of two weeks, proring that the contamination, in the case of theseeds, must have comefrom the seeds themselves.

5. The foregoing work has convineed me that the results of formerly published workare open to criticism in at least two respects: No adequate proof 
is giventhat the seeds are really freefrom contaminating organisms and no means are employed to remove the disinfectant so thoroughly that it can no $10 \mathrm{ger}$ act as an antiseptic. In view of the foregoing results, we are foreed to conclude that the majority of cases of so-called disinfection were merely cases of antisepsis.

6. To antisepsis, and not to disinfection, we must probably lookfor practical results. It makes no difference in physiological experimentation whe ther a few dormant organisms cling to the seed lings or not. What does the harm is theiractive growth and multiplication. Absolutedesinfection, which seems out of the question at present, is not essent i i 1 .

\section{Note.}

$\mathrm{S}$ in $\mathrm{c}$ e the completion of the foregoing work, which was not published as soon as desired owing to mavoidable delays, several publications have appeared bearing on the same topic. Two of these are especially worthy of notice. B $\mathrm{row} \mathrm{n}^{1}$ ) has shown that the seed-coats of $\mathrm{H}$ or de u m v ul ga re caemleseens are readily penetrated by mereuric chloride and some other agents, while sulphuric acid and copper sulphate affect it less guichly. He attributes this to a ,selective action" of the seed-coat. I had noticed the same thing, but did not have an explanation for it. This perhaps accounts for the fact that I was unable to obtain seedlings from $\mathrm{Horde} \mathrm{u} \mathrm{m,} \mathrm{ex-}$ cept when I worked with cleaning fluid.

The second paper is by $R 0 b$ in $\mathrm{s}_{0} \mathrm{n}^{2}$ ). The purpose of this work was to obtain ,some definite knowledge of the effects produced by sterilization", thus admitting at the outset that there is undoubtedly a residual effect of sterilization that must be reckoned with. Thus the anthor takes practically the same ground that I have taken in the preceding paper.

Both leguminous and non-leguminous seeds were used. Fifty seeds of each of seven different linds were used. The seeds wore treated with the disinfertants, then rinsed several times in sterile, distilled water a precaution many do not use) and germinated on moist, sterile filter paper in sterile Peefi dishes. After the seeds had been in the Potri dishes for scrveal diays, platings were made on beef agar from the seeds.

From the author's paper I infer that he did not subject his seeds to as long and thorough washing as I did. That is the only way I can explain the difference between his results and mine. For instance, he found that wheat. and corn were sterile after treating them for one hour with commercial hydrugen peroxide. In my work I found that they were not sterile even after treating wheat four hours and com five hours. The gemination pereentage was pratetically the same in his case and mine. The author himself calls attention to the fact that enough disinfectant may adhere to the seeds to cause antirepsis. Thus, some seeds of pea, wheat and radish were treated for thirty minutes with a 0.5 percent solution of mercuric chloride, they were then washed three times and the third wash water was used for plating $\mathrm{B}$ a $\mathrm{c}$ ill u s s u b-

1) Proceed. of the Roy. Soc. London. Vol. 81. Ser. B. p. 82.

$\left.{ }^{2}\right)$ U. S. Dept. of Ag, Bur. of Plt. Ind. Circ. No. 67. 
tilis. At the end of the period of incubation the plates were sterile, showing that enough mercuric chloride remined on the seeds after two washings to make the third wash water so toxic that it inhibited the growth of Bacillus subtilis. Formaldehyde and hydrogen peroxide showed the same results, unless used in a very weak solution and for a very short time.

The author also found that air-bubbles on or in the seeds interfered with the action of the disinfectant. To overenme this difficulty he used a vacuummump. The results are described as .good but not perfect". I found treating them for a moment with 70 percent alcohol satisfactory. If the vacuumjump is used, the disinfectant is apt to penetrate too deeply to be readily removed.

\section{Bibliography.}

A'b ba u. Ro ndelli, Das Atzululimat und das Formaldehyd in der Desinfektions. praxis. (Centralbl. f. Bakt. Abt. I. Orig. Bd. 33. 1903. p. 821; Ann. Rept. Bd. of Health of Mass. vol. 33. 1905. p. 207.)

Behring. Üher Queckilheralbuminat in eiweißhaltigen Flüssigkeiten. (Centralbl. f. Bakt. Bd. 3. 1888. p. 27.)

Bolley, Einige Bemerkungen über die symbiotische Mykoplasmatheorie bei dem Getreiderost. (Centralbl. f. Bakt. Abt. II. Bd. 4. 1898. p. 855.)

$\mathrm{B}$ oll e y and Prit chard, Internal infection of the Wheat grain by rust. (Science. N. Ser. Vol. 22. 1905. p. 343.)

B o s e, Essais de desinfection par le vapeur de formaldehyde. (Ann. de l'Instit. Pasteur. T. 10. 1896. p. 299.)

$\mathrm{Br}$ a a $\mathrm{t} z$, Über eine bisher unbeachtete Eigenschaft des Alkohols bei seiner Verwendung zur Händereinigung. (Münchner med. Wochensehr. Bd. 54. 1900. p. 1421.)

$\mathrm{Burm}$ ester, Vergleichende Untersuchungen über den Einfluß der verschiedenen Samenheizmethoden auf die Keimfähigkeit seleizten Saatgutes und über ihre pilztötende Wirkung. (Zeitschr. f. Pflanzenkrankh. Bd. 18 1908. p. 154.)

$\mathrm{C} h$ ester and B r ow n, On the action of Formaldehydo in the preservation of milk. (Centralbl. f. Bakt. Abt. II. Bd. 15. 1905. p. 629.)

C z a p e k. Zur Lehre von den Wurzelausscheidungen. (Jahrb. f. wiss. Bot. Bd. 29. 1896. p. 337.)

Danielsohn u. Hess, Alkohol und Sublamin als Händedesinfektionsmittel. (Deutsche med. Wochenschr. Bd. 28. 1902. p. 1112.)

Eriksson, A general Review of the principal Results of Swedish Research into Grain Rust. (Bot. Gaz. Vol. 25. 1898. p. 26.)

- The vegetative Life of some Uredineae. (Ann. of Bot. Vol. 19. 1905. p. 55.)

Freeman, The Seed-Fungus of Loli um tem u lentum. (Philos. Trans. Roy, Soc. of London. B. Vol. 196. 1904. p. 1.)

F ï $\mathrm{rbringer}$ und Frey han, Neue Untersuchungen über die Desinfektion der Hände. (Deutsch. med. Wochenschr. Bd. 23. 1897. p. 81.)

G e p p e r t, Zur Lehre von den Antisepticis. (Berlin. klin. Wochenschr. Bd. 26. 1889. p. 1182.$)$

-. Ưher desinfizierende Mittel und Wethoden. (Berlin. Klin. Wochenschr. Bd. 27. 1890. p. 312.)

-, Die Desinfektionsfrage. (Deutsch. med. Wochenschr. Bd. 17. 1891. p. 797.)

Grawitz, Bemerkung zum Artikel von M a y er und Wolpert, Úber ,Wohnungsdesinfektion durch Formaldehyd". (Hyg. Rundschau. Bd. 11. 1901. p. 395.)

$\mathrm{H}$ a $\mathrm{n} \mathrm{n}$ ig, Über pilzfreies L o lium te mule $\mathrm{tum}$. (Bot. Zeitg. Bd.65. 1907. p. 27.)

-, Die Bindung freien atmosphärischen Stickstoffs durch pilzhaltiges L o li u m te m u l e n t u m. (Ber. d. Deutsch. Bot. Gesellsch. Bd. 26. p. 238. 1908.)

$\mathrm{H}$ a r ris on and Barlow, The Nodule Organism of the Leguminosae - Its Isolation, Cultivation, Identification and commercial Application. (Centralbl. f. Bakt. Abt. II. Bd. 19. 1907. p. 264.)

K e h l e r, Uber die Sterilisation des Erdbortens und Pflanzensamen und über zwei thermoresistente Bakterien. [Diss.] Königsberg i. Pr. 1904.

H i lgerma nn, Wasseratoffuperoxyl als Reinigungs- und Desinfelitionsmittel im Friseurgewerbe. (Arch. f. Hyg. Bd. 14. 1892. p. 40.)

K elh of er, Uber die Ansführung und die Ergebnisse von Haftfestigkeitsversuchen kupferhaltiger Bekämpfungsmittel gegen die Peronospora. (Zeitschr. f. Pflanzenkrankh. Bd. 17. 1907. p. 1.) 
K r a e m e r, Dilute Sulphuric Acid as a Fungicide. (Proc. Amer. Phil. Soc. Vol. 45. 1906. p. 157.)

K r ön i g u B l u m b e rg, Vergleichende Untersuchungen über den Wert der mechanischen und Alkoholdesinfektion der Hände gegenïber der Desinfektion mit Quecksilbersalzen. (Münchener med. Wochenschr. Bd. 47. 1900. p. 29.)

II a y e $\mathrm{r}$ u. W o l p e r t, Zur Rolle der Lufttemperatur bei der Formaldehyddesinfektion. (Hyg. Rundschau. Bd. 11. 1901. p. 396.)

-. Wohnungsdesinfektion dureh Formaldehyd. (Hyw. Rundschan. Bd. 11. 1901. p. 153.)

M j y a jima, On the poisonous Action of Copper upon various Plants. (Bot. Mag. Tokyo. Vol. 11. 1897. p. 417.)

M o r s e, Potato Diseases in 1907. (Bull. Me. Agd. Exp. Stat. 149. 1907.)

II ii ll e r, Vergleichende Untersuchungen über die desinfizierende Wirkung und die räumliche Verteilung des Formaldehyds bei dem Versprayungs- und Verdämpfungsverfahren. (Centralbl. f. Bakt. Abt. I. Orig. Bd. 30. 1901. p. 454.)

Nels on, Some Potato Diseases. (Bull. Wyo. Exp. Stat. 71. 1907.)

Novy and W a ite, The Disinfection of Rooms. (Sep. Rep. to the Mich. State Bd. of Health. 1898.)

$\mathrm{Pammel}$, Anatomical Characters of the Seeds of Leguminosae, chiefly Genera of Gr a y s Manual. (Trans. Acad. Sci. of St. Louis. Vol. 9. 1899. p. 1.)

Park, Pathogenic Bacteria and Protozoa. (Lea \& Febiger) New York. 1905.

$P$ a u l, Entwurf auf einheitliche Werthestimmung chemischer Desinfektionsmittel, mit besonderer Berï̈.ksichtigung der neuen physikalisch-chemischen Theorien der Lösungen. (Zeitschr. f. ang. Chemie. Bd. 14. 1901.p. 333.)

$\mathrm{P}$ a u l u. K r ön i g, Über das Verhalten der Bakterien zu chemischen Reagentien. (Zeitschr. f. physik. Chem. Bd. 21. 1896. p. 414.)

Puriewitsch, Physiologische Untersuchungen über die Entleerung der Reservestoffbehälter. (Jahrb. f. wiss. Bot. Bd. 31. 1898. p. 1.)

R a h $n$, Die Empfindlichkeit der Fäulnis- und Milchsiture-Bakterien gregen Gifte. (Centralbl. f. Bakt. Abt. II. Bd. 14. 1905. p. 21.)

$\mathrm{Re} t \mathrm{tg}$ er and End i c o t $\mathrm{t}$, The Use of Copper in the Purification of Water. (Eng. N ws. Vol. 56. 1906. p. 425.)

$\mathrm{R}$ ide a 1, Disinfection and the Preservation of Food. New York (J. Wiley \& Sons). 1903 .

$\mathrm{R} u \mathrm{~b}$ e r $u$. P e e r e b o o m, Beiträge zur Theorie un $\mathrm{l}$ Praxis der Formaldehyd. desinfektion. (Hyg. Rundschau. Bd. 9. 1899. p. 265.)

Salmon, Further cultural Experiments with biologic Forms of the Erysiphaceae. (Ann. of Bot. Vol. 19. 1905. p. 127.)

-, On endophytic Adaptation shown by Erysiphe gramin is under cultural Conditions. (Abstract of paper read before the Roy. Soc. of London. Apr. 6; 1905; Ann. of Bot. Vol. 19. 1905. p. 444.)

St e r n berg, A Text-Book of Bacteriology. New York (W. Wood \& Co.). 1901.

S t e w a rd, On endospermic Respiration in certain Seeds. (Ann. of Bot. Vol. 22. 1908. p. 415 )

Werner, Zur Kritik der Formaldehyddesinfektion. (Arch. f. Hyg. Bd. 50. 1904. p. 305.)

Wh e tz e 1, Some Diseases of Beans. (Bull. Cornell Univ. Agr. Exp. Stat. 239. 1906. 




LIBRARY OF CONGRESS

||||||| |

0000933?015 